ECONOMICS

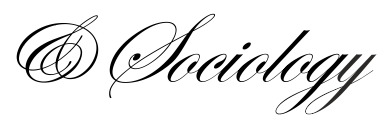

\title{
THE INFLUENCE OF SME OWNERS' EDUCATION ON THEIR PERCEPTION OF BUSINESS ENVIRONMENT IN CZECH REPUBLIC
}

\begin{abstract}
The aim of this article is to find out how SME owners in Czech Republic perceive the role of the state and whether this perception differs according to their level of education. In the course of this project managers or owners of small and medium enterprises were asked to answer the questions about business environment. The following three variables influencing business environment had been chosen: conditions for starting a business, state financial support for business, improving conditions for business in a longer-term pespective. For each of the answers, ordinal mean values were searched for, and discrete ordinal variances were calculated. In order to test for the dependencies, Pearson's Chi-squared test was applied. It was found that the lower education the businesspersons have, the higher is their satisfaction with the role of the state in the business environment of Czech Republic. Better-educated businesspersons are more aware of administrative obstructions when starting a business. Majority of SMEs were not satisfied with the financial support for businesses provided the state.
\end{abstract}

Received: February, 2017

1st Revision: May, 2017

Accepted: July, 2017

DOI: $10.14254 / 2071-$

789X.2017/10-3/22
JEL Classification: H70, L26, M13, M21
Keywords: business environment, small and medium-sized enterprises, state, education

\section{Introduction}

Small and medium-sized enterprises play an important role in both domestic and international economic environments. They enter the international division of labour either directly through contacts with foreign partners, or indirectly, through importing and exporting as subcontractors. Under the increasing liberalization of international trade, their activity continues to grow (Dúbravská et al., 2015).

According to the initiative called the Small Business Act, Czech Republic is more or less at the EU average level in such fields as entrepreneurship, access to finance, the single market, skills and innovation, but is significantly below the average in the area of the second chance, "Green light to Small and Medium-Sized Enterprises", flexible management, state support, public procurement and internationalization (European Commission, 2015).

Quality business environment is a prerequisite for long-term competitiveness and growth of every market economy. In its broadest sense, business environment reflects the 
quality of economic conditions and preconditions of economic activities of enterprises. Belanová (2014) states that quality business environment creates conditions for long-term sustainable economic growth, and is a basic prerequisite for business development and competitiveness growth of countries on the international scale.

In this article, the current state of business environment for SMEs in the selected regions of Czech Republic has been examined.

The structure of the article is as follows. In the theoretical part, we ground the importance of business environment and differences in perception of business environment from the viewpoint of entrepreneurs' different education. Based on the empirical research on the quality of business environment in Czech Republic, we quantify med(x) and ordinal variance (dorvar) and Pearson's Chi-squared test, and we compare differences in perception by Czech entrepreneurs in relation to their education. At the end of this paper, we present the main results of our research.

\section{Literature review}

The definition of SME can be found in the Recommendation of the European Commission 2003/361. According to EC (2015), the main factors determining if a company belongs to the SME segment are number of employees and annual turnover or the annual balance sheet total. We can recognize three categories of enterprises: Micro (less than 10 employees, turnover or balance sheet total $\leq 2$ million EUR), Small (less than 50 employees, turnover or balance sheet total $\leq 10$ million EUR), Medium-sized (less than 250 employees, turnover $\leq 50$ million EUR or balance sheet total $\leq 43$ million EUR).

SMEs are important not only in Czech Republic, but also in EU and they influence economic performance of each state. It is understandable that they are of interest to many studies of different authors (Ivanova \& Koisova, 2014).

The World Bank annually compares regulations of business environment in the world economies through the ranking called Doing Business, which provides objective measures of business regulations for local firms in 185 economies and selected cities at the subnational level. The rank of each country is determined on the basis of indicators, which monitor different phases of SMEs' life cycle, beginning from establishment of the company by acquiring building permits, receiving the bank loans, continuing by enforcement of contracts up to the closing of legal entities. The aim of this project is to provide a reasonable basis for understanding and improving the regulatory environment for business. The latest report published in 2016, puts Singapore, New Zealand and Denmark on the first three places, while the Czech Republic was on 36th place (has moved 39 positions higher since 2014). The Czech Republic was presented as the one with highest improvement (The World Bank, 2016).

Czech companies with up to 250 employees experienced a good year and nearly 40 percent of them expect further improvement in the second half of this year. Then, the greatest optimism prevails among medium-sized companies (51-250 employees). It comes from the present results of "Chamber barometer" that maps the economic situation among the members of Chamber within a semi-annual period (Ministry of Industry and Trade, 2017).

Quality business environment creates favourable conditions for development of SMEs, which represent an important part of the national economic system. Not only economic criteria, but also social, educational, cultural and other factors are playing an important role in this process (Ključnikov et al., 2016; Smekalova et al., 2014). Taraba et al. (2015) states that also holistic competences of entrepreneurs are very important in the context of risk management. A holistically competent project manager should possess developed expertise, practical skills and personal qualities. 
Business activities are significantly determined by environment of the company, which forces it to use a particular method of behaviour and to choose particular business goals and ways of achieving them. In this context, important roles are played by social environment as well as political and legal environments that are created by the state authorities. Presumably, a positive perception of these companies by their environment could stimulate their financial performance and accelerate the positive influences of these companies on society (Belás et al., 2015).

Gnyawali and Fogel (1994) advert to significance of the business environment itself. A highly munificent environment for entrepreneurs is characterized by a strong presence of family business and role models, rich infrastructure, the availability of skilled resources, a solid financial community, and government incentives to start a new business.

Ulhoi (2004) highlights that attention is often paid to identification and characterization of various personal attributes that relate to successful entrepreneurs. However, besides others, this approach diverts attention from the importance of environment and structural and positional characteristics of the entrepreneurs themselves (e.g., gender and race, but also the social network surrounding of the entrepreneur).

The perception of business environment and company operations may also be affected by education of an entrepreneur. The higher education of an entrepreneur is, the wider knowledge of economic regularities of the market and the more accurate forecasting of the circumstances in business environment are.

Some authors found out that higher entrepreneurs' education such as university degree is significantly related to a higher business performance when it is calculated when sales or profitability is concerned and which is also true for sustainability (Van der Sluis, and Van Praag, 2008), also, higher educated entrepreneurs can manage the firm-specific financial risks better (Wang, 2012). According to Kato, Okamuro, and Honjo (2015), a graduate entrepreneur can easily find different sources of capital, by which he/she can invest in research and development that can increase the innovation of a small business from the specific market.

According to Berrone et al. (2014), gender cannot influence the performance of a firm if an entrepreneur is educated enough or motivated enough to run business.

Micro enterprises owned by educated professionals have lower credit risk and as a result, they can access loans under lower interest rates. Furthermore, micro firms' access to credit largely depends on the managerial ability and professional expertise of entrepreneurs. In that case, they can get access to bank loans more easily when a firm is well managed and when the owner is more experienced (Neuberger and Rathke, 2009).

Educated entrepreneurs are more successful than those who are not educated enough to run their businesses (Berrone et al., 2014). Micro enterprises run by educated personnel are more linked to strategic alliances and also develop new products continuously to meet the demand of customers (Kim and Vonorts, 2014).

According to Irwin and Scott (2010), the banks were more comfortable to finance the educated entrepreneurs due to advanced knowledge of the business propositions and more organized loan proposals. The higher education of the entrepreneur is positively related to business growth (Rauch and Rijsdijk, 2013).

\section{Methodological approach}

The aim of this article is to examine the influence of education on differences in perception of the role of state in business environment in the segment of SMEs in the Czech Republic. The reason for the focus on SMEs is their importance and flexibility in the economy of the Czech Republic and all over the world. The article presents the partial results 
of the research which was conducted at Tomas Bata University in Zlín in the Czech Republic in 2015. The companies had been chosen from the Albertina database and 1.650 randomly selected firms were addressed by e-mail or phone to fill in the questionnaire placed at https://docs.google.com/forms/d/1U9coaC5JRL0N2QOOO6Xb8j3mnaZXdSM47Kugt4EDG Fo/viewform?usp=send_form. The data was provided by 1.141 owners of SMEs in 14 regions of the Czech Republic. The questionnaire consisted of 52 questions.

The structure of the sample researched according to the size of enterprises was as follows: $65 \%$ of Micro enterprises ( $<10$ employees), 27\% of Small enterprises (1050 employees) and 8\% of Medium-sized enterprises (50-250 employees). This structure also corresponds to the allocation of enterprises in the economy.

Regarding owners of the enterprises questioned, their educational structure was concerned. The highest number of SME owners questioned was with secondary education with A levels (48\%). Businesses, of which the owners have university degree, were represented by $34 \%$. The smallest number of the owners within the sample researched is the group of those with secondary education without A levels (18\%).

The article is focused on the analysis of the partial research results in the following three sectors that were surveyed when studying SMEs. The concentration was on their present attitude to selected factors of business environment in the Czech Republic.

By creating research question we followed results from previous researches Belanová (2014), Belás et al. (2015), Ključnikov (2016), Dobeš, Virglerová (2015).

1. Perception of business environment in the Czech Republic as a suitable one for starting a business:

Q1: At least 30\% of SME owners in the Czech Republic state that business environment is suitable for starting a business.

Q1a: University-educated entrepreneurs perceive business environment of the Czech Republic as more suitable for starting a business than those without university degree.

Q1b: Perception of business environment of the Czech Republic as a suitable one for starting a business is dependent on entrepreneurs' education.

2. Perception of forms of financial support of business from the state:

Q2: More than $50 \%$ of SME entrepreneurs in the Czech Republic perceive the financial support of business from the state as not sufficient.

Q2a: University-educated entrepreneurs perceive the financial support of business from the state as more suitable than those without university degree do.

Q2b: Perception of the financial support of business form the state is dependent on entrepreneurs' education.

3. Perception of having better conditions for doing business in the course of the last 5 years:

Q3: More than $50 \%$ of SME entrepreneurs do not agree that conditions for doing business have improved in the course of the last 5 years.

Q3a: University-educated entrepreneurs are aware of the fact that in the course of the last 5 years, conditions for doing business have improved, on contrary to those without university degree.

Q3b: Perception of better conditions for doing business in the course of the last 5 years is dependent on entrepreneurs' education.

For each of the answers, ordinal mean values $-\operatorname{med}(\mathrm{x})$ were searched for, and discrete ordinal variances - dorvar was calculated. In order to test dependencies, Pearson's Chisquared test was used. The X-squared tests were done at 5\% level of importance. For the reason of not having a sufficient number of several groups within the sample researched, the Monte Carlo simulation was used. This method shall eliminate drawbacks and will provide a more precise $\mathrm{p}$-value. 


\section{Conducting research and results}

The first research question (Q1) focuses on the analysis of how the businesses questioned perceive business environment of the Czech Republic for starting a business. This question was then analysed in relation to the entrepreneurs' education reached.

The research revealed that $29.62 \%$ of entrepreneurs agree with the fact that business environment of the Czech Republic is suitable for starting a business. $24.98 \%$ of the respondents had neutral attitude and less than half of the entrepreneurs questioned $(45.4 \%)$ do not agree with the statement. The research question Q1 that at least 30\% of SME entrepreneurs in the Czech Republic consider the business environment to be suitable for starting a business was not confirmed.

Table 1 shows nominal values of the statement to Q1 in relation to the entrepreneurs' education reached. In Tab. 1, ordinal mean values and discrete ordinal variances are stated.

Table 1. Contingency table for Q1 absolute frequency and Statistical characteristics

\begin{tabular}{lcccccccc}
\hline \multirow{2}{*}{ Q1/Education } & \multicolumn{2}{c}{ Agree $(n)$} & - & \multicolumn{2}{c}{ Disagree $(n)$} & $\begin{array}{c}\text { Total } \\
(n)\end{array}$ & \multicolumn{2}{c}{$\begin{array}{c}\text { Statistical } \\
\text { indicators }\end{array}$} \\
\cline { 2 - 10 } & $\begin{array}{c}\text { Completely } \\
\text { agree }\end{array}$ & Agree & $\begin{array}{c}\text { No } \\
\text { idea }\end{array}$ & Disagree & $\begin{array}{c}\text { Completely } \\
\text { disagree }\end{array}$ & & med $(x)$ & dorvar \\
\hline $\begin{array}{l}\text { Secondary } \\
\text { without A levels }\end{array}$ & 2 & 41 & 55 & 91 & 17 & 206 & 2.45 & 1.00 \\
\hline $\begin{array}{l}\text { Secondary with } \\
\text { A levels }\end{array}$ & 8 & 167 & 129 & 207 & 32 & 543 & 2.75 & 1.07 \\
\hline University & 5 & 115 & 101 & 148 & 23 & 392 & 2.75 & 1.05 \\
\hline Total & 15 & 323 & 285 & 446 & 72 & 1141 & & \\
\hline
\end{tabular}

Source: own.

The opinion polarity to Q1 is depicted in the graph below by using the Gauss distribution model (blue) with a polynomial function of trend (black thin) with the value of reliability (R2). The axis $x$ represents the following: $0=$ completely disagree, $1=$ completely agree.

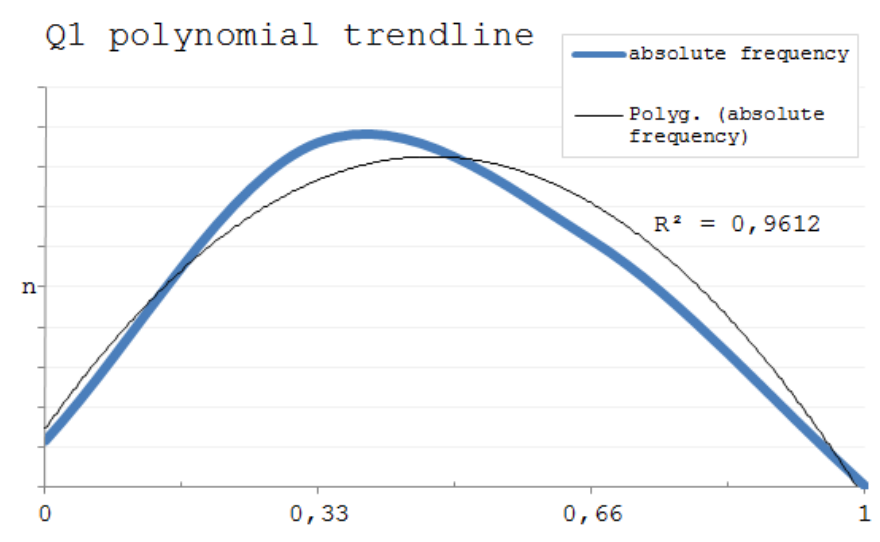

Graph 1. Q1 line chart with trend line Source: own.

The line chart represents opinion polarity using the Gauss distribution model. It is evident from the graph that opinion of disagreement slightly prevails, even though the trend 
function rather equalizes both poles. Regarding the fact that closer the value of R2 is to 1 , more reliable the result is. In this case, the reliability is high $(\mathrm{R} 2=0.9612)$.

Q1a research question focuses on if university-educated entrepreneurs perceive the business environment of the Czech Republic as a more suitable one for starting a business than those without university degree. The highest degree of agreement $(\operatorname{med}(x)=2.45)$ with the statement to the question researched was recorded by the entrepreneurs with secondary education without A levels. There was also rather high homogeneity of their answers (dorvar $=1$ ). The degree of agreement with this statement within the group of entrepreneurs with having A levels and university-educated ones was the same $(\operatorname{med}(x)=2.75)$. To be more precise, the secondary educated entrepreneurs with A levels were most heterogeneous in their answers (dorvar $=1.07$ ). When evaluating this research question, it can be stated that entrepreneurs with a higher level of education reached are more aware of various obstacles and problems when starting business activities in the Czech Republic.

Table 2 shows the dependency testing results by analysing Q1b research question focusing on if there is any dependency between perceiving the business environment in the Czech Republic as a suitable one for starting a business and the entrepreneurs' education reached. For testing, Pearson's Chi-squared test at 5\% level of importance was used.

Table 2. Q1 Chi-squared test and p-value

\begin{tabular}{l}
\hline Pearson's Chi-squared test with simulated p-value (based on 5000 replicates) \\
\hline $\mathrm{H}_{0}:$ Variables are independent (no interaction between variables) \\
$\mathrm{H}_{1}$ : Variables are dependent (interaction between variables) \\
\hline $\mathrm{Q}_{1 \mathrm{~b}}: 1$. Perception of business environment in the Czech Republic as a suitable one for starting a \\
business is dependent on entrepreneurs' education. \\
\hline $\mathrm{X}$-squared $=10.57 ; \mathrm{DF}=\mathrm{n} / \mathrm{a} ; \mathrm{p}$-value $=0.2244$ \\
\hline
\end{tabular}

Source: own.

The results in Table 2 show that no statistically important dependency between the perception of business environment of the Czech Republic as a suitable one for starting a business and entrepreneurs' education was confirmed.

The second research question (Q2) focuses on analysing the topic of if the entrepreneurs perceive financial support of business from the state as sufficient. This question was then analysed in relation to the level of education of the entrepreneurs questioned.

The research showed that only $9.55 \%$ of entrepreneurs consider the financial support of business from the state to be sufficient. More than half of the entrepreneurs questioned (59.07\%) do not agree with this statement. $31.38 \%$ of respondents had a neutral attitude. Most of businesspersons are therefore not satisfied with the support of business from the state. The statement to the research question (Q2) that more than 50\% of SME entrepreneurs in the Czech Republic perceive the financial support of business from the state as not sufficient was confirmed.

Table 3 shows nominal values of the statement to Q2 in relation to the level of education of the entrepreneurs questioned. In Tab. 3, there are also ordinal mean values and discrete ordinal variances recorded. 
INTERDISCIPLINARY APPROACH TO ECONOMICS AND SOCIOLOGY

Table 3. Contingency table for Q2 absolute frequency and Statistical characteristics

\begin{tabular}{lcccccccc}
\hline \multirow{2}{*}{ Q2/Education } & \multicolumn{2}{c}{ Agree $(n)$} & - & \multicolumn{2}{c}{ Disagree $(n)$} & $\begin{array}{c}\text { Total } \\
(n)\end{array}$ & \multicolumn{2}{c}{$\begin{array}{c}\text { Statistical } \\
\text { indicators }\end{array}$} \\
\cline { 2 - 9 } & $\begin{array}{c}\text { Completely } \\
\text { agree }\end{array}$ & Agree & $\begin{array}{c}\text { No } \\
\text { idea }\end{array}$ & Disagree & $\begin{array}{c}\text { Completely } \\
\text { disagree }\end{array}$ & & med $(x)$ & dorvar \\
\hline $\begin{array}{l}\text { Secondary } \\
\text { without A levels }\end{array}$ & 0 & 12 & 62 & 95 & 37 & 206 & 2.19 & 206 \\
\hline $\begin{array}{l}\text { Secondary with A } \\
\text { levels }\end{array}$ & 2 & 48 & 170 & 262 & 61 & 543 & 2.30 & 543 \\
\hline University & 0 & 47 & 126 & 173 & 46 & 392 & 2.37 & 392 \\
\hline Total & 2 & 107 & 358 & 530 & 144 & 1141 & & \\
\hline
\end{tabular}

Source: own.

The opinion polarity to Q2 is depicted in the graph below by using the Gauss distribution model (blue) with a polynomial function of trend (black thin) with the value of reliability (R2). The axis $x$ represents the following: $0=$ completely disagree, $1=$ completely agree.

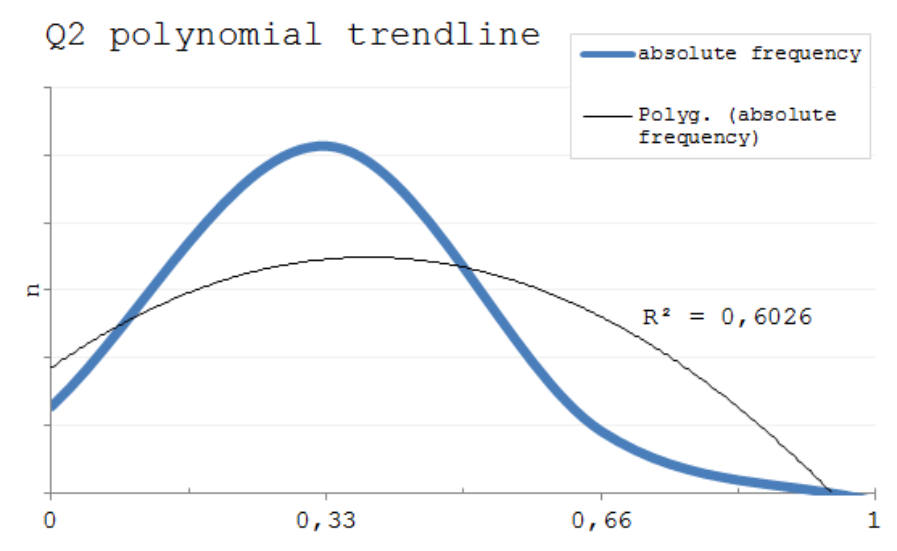

Graph 2. Q2 line chart with trend line

Source: own.

The line chart represents opinion polarity using the Gauss distribution model. It is evident from the graph that opinion of disagreement slightly prevails, even though the trend function rather equalizes both poles. Regarding the fact that closer the value of R2 is to 1 , more reliable the result is. In this case, the reliability is not high $(\mathrm{R} 2=0.6026)$.

Q2a research question focuses on if university-educated entrepreneurs perceive the financial support of business from the state as a more suitable one than those without university degree. The highest degree of agreement $(\operatorname{med}(x)=2.19)$ with the statement researched was recorded by the entrepreneurs with secondary education without A levels. There was also rather high homogeneity of their answers (dorvar $=0.86$ ). On the other hand, the lowest degree of agreement with the statement to the question researched was recorded by the entrepreneurs with university education $(\operatorname{med}(\mathrm{x})=2.37)$ and at the same time, the homogeneity of their answers was lowest (dorvar $=0.91$ ). When evaluating this research question, it can be stated that entrepreneurs with a lower level of education reached are more satisfied with the financial support of business from the state.

Table 4 shows the dependency testing results by analysing Q2b research question focusing on if there is any dependency between perceiving the financial support of business 
from the state as sufficient and the entrepreneurs' education reached. For testing, Pearson's Chi-squared test at 5\% level of importance was used.

Table 4. Q2 Chi-squared test and p-value

\begin{tabular}{l}
\hline Pearson's Chi-squared test with simulated p-value (based on 5000 replicates) \\
$\mathrm{H}_{0}$ : Variables are independent (no interaction between variables) \\
$\mathrm{H}_{1}$ : Variables are dependent (interaction between variables) \\
\hline $\mathrm{Q}_{2 \mathrm{~b}}$ : Perception of forms of financial support of business from the state is dependent on \\
entrepreneurs' education reached. \\
\hline $\mathrm{X}$-squared $=14.74 ; \mathrm{DF}=\mathrm{n} / \mathrm{a}$; $\mathrm{p}$-value $=0.06659$ \\
\hline
\end{tabular}

Source: own.

The results in Table 4 show that no statistically important dependency between the perception of the financial support of business from the state as sufficient and entrepreneurs' education was confirmed.

The third research question (Q3) focuses on analysing if the entrepreneurs agree with the fact that conditions for doing business have improved in the course of the last 5 years. This question was then analysed in relation to the level of education of the entrepreneurs questioned.

The research showed that $20.68 \%$ of entrepreneurs consider conditions for doing business in the course of the last 5 years to have improved. $24.63 \%$ of respondents had a neutral attitude. More than half of the entrepreneurs questioned (54.69\%) do not agree with this statement. The statement to the research question (Q3) that more than $50 \%$ of SME entrepreneurs in the Czech Republic perceive conditions for doing business as being better in the last few years was confirmed.

Tab. 5 shows nominal values of the statement to Q3 in relation to the level of education of the entrepreneurs questioned. In Tab. 5, there are also ordinal mean values and discrete ordinal variances recorded.

Table 5. Contingency table for Q3 (relative frequency) and Statistical characteristics

\begin{tabular}{|c|c|c|c|c|c|c|c|c|}
\hline \multirow{2}{*}{ Q3/Education } & \multicolumn{2}{|c|}{ Agree (\%) } & \multirow{2}{*}{$\begin{array}{c}- \\
\text { No } \\
\text { idea }\end{array}$} & \multicolumn{2}{|c|}{ Disagree (\%) } & \multirow{2}{*}{$\begin{array}{c}\text { Total } \\
(\%)\end{array}$} & \multicolumn{2}{|c|}{$\begin{array}{l}\text { Statistical } \\
\text { indicators }\end{array}$} \\
\hline & $\begin{array}{l}\text { Completely } \\
\text { agree }\end{array}$ & Agree & & Disagree & $\begin{array}{c}\text { Completely } \\
\text { disagree }\end{array}$ & & $\operatorname{med}(x)$ & dorvar \\
\hline $\begin{array}{l}\text { Secondary } \\
\text { without A } \\
\text { levels }\end{array}$ & 0.00 & 16.02 & 16.50 & 50.97 & 16.50 & 100.0 & 2.16 & 0.98 \\
\hline $\begin{array}{l}\text { Secondary } \\
\text { with A levels }\end{array}$ & 0.74 & 19.71 & 25.23 & 47.51 & 6.81 & 100.0 & 2.41 & 0.96 \\
\hline University & 0.77 & 22.70 & 28.06 & 39.03 & 9.44 & 100.0 & 2.55 & 1.04 \\
\hline $\begin{array}{l}\text { Total Relative } \\
\text { share }(\%)\end{array}$ & 0.61 & 20.07 & 24.63 & 45.22 & 9.47 & 100.0 & & \\
\hline
\end{tabular}

Source: own.

The opinion polarity to Q3 is depicted in the graph below by using the Gauss distribution model (blue) with a polynomial function of trend (black thin) with the value of 
reliability (R2). The axis $\mathrm{x}$ represents the following: $0=$ completely disagree, $1=$ completely agree.

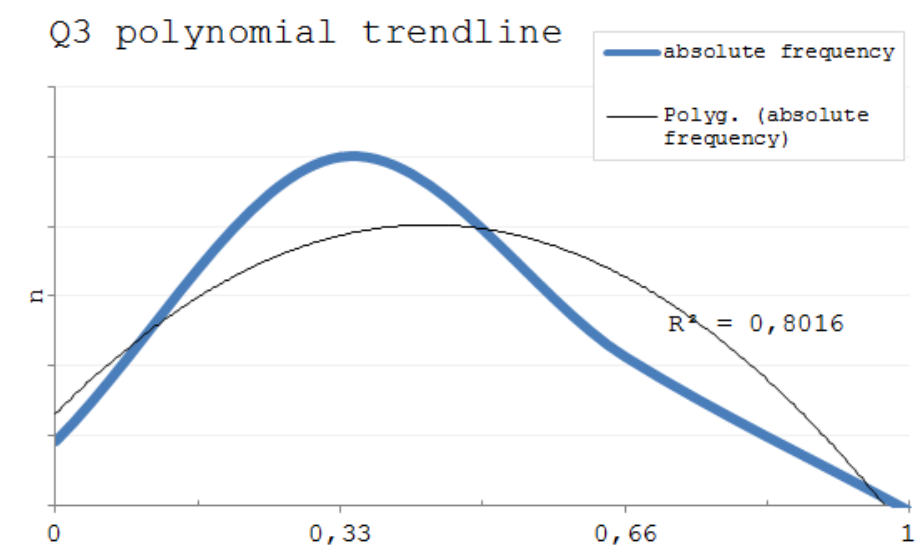

Graph 3. Q3 line chart with trend line

Source: own.

The line chart represents opinion polarity using the Gauss distribution model. It is evident from the graph that opinion of disagreement slightly prevails, even though the trend function rather equalizes both poles. Regarding the fact that closer the value of R2 is to 1 , more reliable the result is. In this case, the reliability is rather high $(\mathrm{R} 2=0.8016)$.

Q3a research question focuses on if university-educated entrepreneurs are aware of the fact that in the course of the last 5 years, conditions for doing business have improved, on contrary to those without university degree. The highest degree of agreement $(\operatorname{med}(x)=2.16)$ with the statement researched was recorded by the entrepreneurs with secondary education without A levels. There was also rather high homogeneity of their answers (dorvar $=0.98$ ). On the other hand, rather low degree of agreement with the statement to the question researched was recorded by the entrepreneurs with university education $(\operatorname{med}(\mathrm{x})=2.55)$ and at the same time, their answers were most heterogeneous (dorvar =1.04). When evaluating this research question, it can be stated that entrepreneurs with a lower level of education reached are more satisfied with the development of business environment of the Czech Republic.

Table 6 shows the dependency testing results by analysing Q3b research question focusing on if there is any dependency between perceiving the conditions for business as having improved in the course of the last 5 years and the entrepreneurs' education reached. For testing, Pearson's Chi-squared test at 5\% level of importance was used.

Table 6. Q3 Chi-squared test and p-value

\begin{tabular}{l}
\hline \multicolumn{1}{c}{ Pearson's Chi-squared test with simulated p-value (based on 5000 replicates) } \\
\hline $\mathrm{H}_{0}$ : Variables are independent (no interaction between variables) \\
$\mathrm{H}_{1}$ : Variables are dependent (interaction between variables) \\
$\mathrm{Q}_{3 \mathrm{~b}}$ : Perception of having better conditions for doing business in the course of the last 5 years and \\
due to entrepreneurs' education reached. \\
\hline $\mathrm{X}$-squared $=32.37 ; \mathrm{DF}=\mathrm{n} / \mathrm{a} ; \mathrm{p}$-value $=2 \mathrm{e}-04$ \\
\hline
\end{tabular}

Source: own. 
The results in Table 6 show that statistically important dependency between the perception of conditions for business in the course of the last 5 years as having improved and entrepreneurs' education was confirmed $(p$-value $=2 \mathrm{e}-04)$. Therefore, it can be stated that within the group of university-educated entrepreneurs, it is evident that these are more aware of all factors forming the business environment and they are able to evaluate their development better. Through the quantitative part of the research, the focus was on data collecting, processing, and analysis. A nine-level Likert scale was used to measure the perceptions and assessments of the respondents, on the dependent variable (transitional crisis), as well as the independent variables (heritage of socialism, geopolitics, nomenclature authorities, deficit of institutional changes, and neoliberal ideology), in a survey that was applied during the research. In measuring the dependent variable (transitional crisis), the scale marks were set from the lowest (1) to the highest (5). Regarding the independent variables, the negative impact was measured from the minimum negative (1) to the maximum (5) on the dependent variable. The survey included filling out 500 questionnaires for each country (Montenegro, Serbia, and Bosnia and Herzegovina), which made a total of 1,500 respondents. Collected data for this study were processed by SPSS software. According to the purpose defined in the hypothesis of work, descriptive statistics were used for the data analysis, correlation analysis, and multi-correlation. The multiple linear regression model was applied after (the method of least square), as well as hierarchical multiple regression model.

\section{Conclusion}

The research focused, besides other things, on the perception of the role of the state among the SME entrepreneurs within the Czech Republic. The state definitely belongs to significant determinants of business environment and its role when doing business can be often crucial either for decision of starting a business or for a successful course of business.

In the research, it was confirmed that half of the SME entrepreneurs questioned does not consider the business environment of the Czech Republic to be convenient for starting a business. This fact can make the enterprises leave the Czech Republic. They would leave for the neighbouring countries or for the countries so-called tax havens where the administration process for starting a business and the business activity itself is much less complicated. According to the Bisnode company, which monitor number of Czech companies with owner from the off-shore every year, is the number of these companies 13185 in the end of the year 2016 (Bisnode, 2017).

In the research, the factor of education and its influence on perception of business environment was analysed in more detail. It was found out that the entrepreneurs with a higher level of education are more aware of the obstacles when starting a business. Moreover, they are also aware of all the factors forming the business environment and they are able to evaluate their development. On the contrary, the entrepreneurs with a lower level of education are more satisfied with the development of business environment in the Czech Republic.

Majority of SMEs in the Czech Republic is not satisfied with the financial support of the state for doing business. Once more, the influence of the factor of education was confirmed. A higher level of education means a higher rate of dissatisfaction with the financial support of the state. A lower level of education means a higher rate of satisfaction as the awareness of information about the forms of business support from the state is rather low. Civelek et al. (2016) also confirmed these results. They state that Czech entrepreneurs rather negatively evaluate the government's approach and its attempts to develop suitable conditions for doing business, the attitude of financial market players to providing the opportunities of external financing for their entrepreneurial activities and current situation in the sphere of 
business risks that are increased due to the crisis. However, they are satisfied with the attitude of their surroundings to their business activities. This area had a higher score in the model.

More than half of the entrepreneurs questioned do not agree with the statement that business conditions in the Czech Republic have improved in the course of the last five years.

The results of this research are not compatible with the conclusions of (Berrone et al., 2014) or (Boyer and Blazy, 2014; Neuberger and Rathke, 2009) about the differences between entrepreneurs with regard to their gender and education. Regarding the perception of business environment and its development mainly, a statistically significant difference in relation to the entrepreneurs' education reached was revealed.

This research has several limitations. First, it is a territorial restriction as the research was done in the Czech Republic only. Therefore, we cannot consider the results to be generally applicable. The questions for the respondents could have been not well formulated or misunderstood by the respondents. Moreover, in connection with corruption and clientelism, the entrepreneurs could have deliberately misinterpreted certain facts.

These research results will be later compared to similar studies from abroad in order to see the influence of the state in the international context.

\section{Acknowledgement}

This paper was supported by the Project RO FaME/2016: Podnikatel'ské prostredie MSP: determinanty kvality a podnikatel'ské riziká.

\section{References}

Belanová, K. (2014). Komparácia kvality podnikatel’ského prostredia v krajinách Vyšehradskej štvorky s osobitným akcentom na dostupnost' fi nančných zdrojov. Biatec, $1,12-17$.

Belás, J., Demjan, V., Habánik, J., Hudáková, M., Sipko, J. (2015). The business environment of small and medium-sized enterprises in selected regions of the Czech Republic and Slovakia. E+M Ekonomie a Management, 18(1), 308-326.

Berrone, P., Gertel, H., Giuliodori, R., Bernard, L., Meiners. E. (2014). Determinants of performance in Microenterprises: Preliminary evidence from Argentina. Journal of Small Business Management, 52(3), 477-500.

Bisnode (2017). Poprvé za deset let meziročně klesl počet firem z daňových rájů. Available at: http://www.bisnode.cz/tiskove-zpravy/poprve-za-deset-let-mezirocne-klesl-pocetfirem-z-danovych-raju/. (reffered on 17/01/2017).

Boyer, T., Blazy, R. (2014). Born To Be Alive? the Survival of Innovative and NonInnovative French Micro Start-Ups. Small Business Economics, 42(4), 669-683.

Civelek, M., Ključnikov, A., Dobrovič, J., Hudáková, M. (2016). A model of measurement of the quality of business environment in SME segment. Journal of International Studies, 9(2), 90-102. DOI: 10.14254/2071-8330.2016/9-2/6.

Dobeš, K., Virglerová, Z. (2015). An Analysis of SME's Attitudes to the Business Environment in the Czech Republic. In: Proceedings of the 19th International Academic Conference. Florence, Italy, International Institute of Social and Economic Sciences (IISES), September 16-19, 235-246.

Dúbravská, M., Mura, L., Kotulič, R., Novotný, J. (2015). Internationalization of Entrepreneurship - Motivating Factors: Case Study of the Slovak Republic. Acta Polytechnica Hungarica, 12(5), 121-133. 
European Commission (2015). 2015 SBA Fact Sheet Czech Republic. Available at: $\mathrm{http} / / /$ ec.europa.eu/growth/smes/business-friendly-environment/performance-review/fi les/countries-sheets/2015/czech-republic_en.pdf.(reffered on 201/03/2016).

European Commission (2015). Které podniky patři do kategorie SME? http://ec.europa.eu/enterprise/policies/sme/facts-figures-analysis/smedefinition/index_cs.htm. (reffered on 06/01/2015).

Gnyawali, D. R. and Fogel, D. S. (1994). Environments for entrepreneurship development: key dimensions and research implications, Entrepreneurship theory and practice, 18(4), 43-63.

Irwin, D., Scott, J. M. (2010). Barriers faced by SMEs in raising bank finance. International Journal of Entrepreneurial Behavior and Research, 16(9), 245-259.

Ivanova, E., Koisova E. (2014). Interregional Disparities in the Slovak and Czech Republic, Economic \& Tourism. SGEM Conferencion Political Sciences Law, Finance, Economics \& Tourism, IV, Sofia: STEF92 Technology, 405-412.

Kato, M., Okamuro, H., Honjo, Y. (2015). Does Founder Human Capital Matter for Innovation? Evidence from Japanese Start-ups. Journal of Small Business Management, 53(1), 114-128.

Kim, Y., Vonorts, N. S. (2014). Managing risk in the formative years: evidence from young enterprises in Europe. Technovation, 34(1), 454-465.

Ključnikov, A., Belás, J., Kozubíková, L., Paseková, P. (2016). The Entreprenurial Perception of SME Business Environment Quality in the Czech Republic. Journal of Competitiveness, 8(1), 66-78.

Ministry of Industry and Trade (2017). Očekávání malých a středních podniků je nejpozitivnější od dob ekonomické krize.

http://www.businessinfo.cz/cs/clanky/ocekavani-malych-a-strednich-podniku-jenejpozitivnejsi-od-dob-ekonomicke-krize-82916.html. (reffered on 17/01/2017).

Neuberger, D., Rathke, S. (2009). Microenterprises and multiple bank relationships: the case of professionals. Small Business Economics, 32(1), 207-229.

Rauch, A., Rijsdijk, S. A. (2013). The Effects of General and Specific Human Capital on long-Term Growth and Failure of Newly Founded Businesses. Entrepreneurship Theory and Practice, 37(4), 923-941.

Smékalová, L., Hájek, O., Belás, J., Macháček, J. (2014). Perception of Small and Medium Entrepreneurship in the Czech Republic. Journal of Competitiveness, 6(4), 41-49.

Taraba, P., Heinzová, R., Pitrová, K., Hart, M., \& Trojan, J. (2015). Project risks in enterprises in the Czech Republic. Paper presented at the Proceedings of the 25th International Business Information Management Association Conference - Innovation Vision 2020: From Regional Development Sustainability to Global Economic Growth. IBIMA 2015, 814-821.

The World Bank (2016). Doing Business 2016. DOI: 10.1596/978-1.

Van der Sluis, J., Van Praag, M. (2008). Education and Entrepreneurship Selection and Performance: A Review of the Empirical Literature. Journal of Economic Surveys, 22(5), 795-841.

Ulhoi, J. P. (2004). The social dimensions of entrepreneurship. Technovation, 25(2), 939-946.

Wang, W. (2012). How the small and medium-sized enterprises' owners' credit features affect the enterprises' credit default behaviour? Journal of Business Management and Economics, 3(2), 090-095. 